\title{
A Turn in the Course of the University Library ${ }^{1}$
}

Dr. White is director of libraries and dean of the School of Library Service, Columbia University.

A STREAM does not follow a straight line. It cuts its path to the sea by twisting and turning to the lay of the land. It is the same with the development of the university library. It cuts a course of its own making except that it too twists and turns to pressures it strikes along the way.

It will vivify this idea and possibly set my later remarks in better historical perspective if we cite an illustration or two. Our university libraries take great pride in the source material they are accumulating daily to support historical and humanistic research. To describe the total volume of these holdings, we would have to resort to such metrical units as miles or acres of shelves. Contrast the collecting policy which is producing this bibliographical acreage with that intimated by Joseph Story in his Phi Beta Kappa oration spoken almost in ear shot of the Harvard campus in 1826 : "There is not," the eminent jurist complained, "perhaps a single library in America sufficiently copious to have enabled Gibbon to have verified the authority for his immortal history of the decline and fall of the Roman Empire."' This is a rather startling pronouncement when read today,

1 Paper presented at meeting of University Libraries

Section, ACRL, July I I I95I, Chicago. Phi Beta Kappa Society at the Anniversary Celebration on the Thirty First Day of August, I826. Boston, Hilliard, Gray, Little, and Wilkins, 1826, p. 49 . but George Livermore, an antiquarian not given to inaccuracy, did not think it was strong enough to describe the situation a quarter of a century later, in I850. Pointing out that even the Gibbon illustration did not originate with Story, Livermore went on to say that "not one, nor all the libraries in this country combined, would furnish sufficient materials for writing a complete history of that little book ... which has had such a mighty influence in moulding the character and creed of former generations, "The New England Primer'". 3 These testimonials tell something about the plight of letters and learning in the young republic, but they tell us also that rocklike pressures were rising up to force a change in the course of the scholarly library.

Another illustration: The second half of the nineteenth century produced an extraordinary series of international exhibitions. When the first one opened in London's Crystal Palace in I85I, no one had any idea that it was going to produce such intense rivalry among nations, but the times were just right. Human work of all kinds, from making cloth to making machines, was being revolutionized. The name we apply to the phenomenon is the Industrial Revolution. No aspect of this revolution was more singular than the way it stemmed from investing all kinds of ordinary work - industry - with greater intelligence. Each civilized nation, quick to see

3 Livermore, George, "Public Libraries." North American Review, 71:186-87, (1850). 
that its future in international trade was bound up with the use of this modern principle, avidly seized upon the international exposition as a kind of testing device for its industrial sinews and know-how. New institutions and new departments in universities arose to enlarge and transmit bodies of knowledge found to have industrial uses. A new era of material progress dawned. And since this modern industrial era rested as it were on libraries of scientific information, a new social policy supporting the extension and application of knowledge soon gained popular favor. These new uses of science and technology gave a new twist to library development, and the university libraries were among those most deeply affected.

We need not dwell longer on the past. My thesis is that terrain is being struck in our time which will force still another important turn in the course. The precise direction eventually taken is going to depend partly on factors beyond our control, partly on how well this generation understands what is taking place and particularly, I suspect, on the number and the stature of those who join together to take thought of the morrow.

There are several relevant factors which are beyond our control; the bulkiness of the graphic record of the mind which it is essential to preserve for research purposes; the expanding rate at which new research materials are being produced, thus further enlarging the basic record; the expanding proportion of the total population which depends on good research library facilities; the ballooning of costs for materials, space and labor; the increasing specialization of interests served by libraries; trends in the distribution of wealth; inflation; and the number and magnitude of other important problems which the public has to think about these days.
These and related influences are precipitating what I shall with your leave refer to as the mid-century crisis of the research library. Universities carry so heavy a share of the burden for present research that we are talking about something singularly important to their libraries, but standing alongside them and equally affected are the research libraries not connected with universities, so the more inclusive term seems to be preferable. This critical situation is being described nowadays by far-seeing observers in language such as the following: ". . . I see nothing which in coming years is to stand between the librarian and an issue of books upon books, so vast and so uninterrupted that unless he brings the benefit of something like science to his aid, he will be overwhelmed and buried in their very mass." It may surprise you to know that the words just quoted were uttered by the President of the Pennsylvania Historical Society in his address of welcome to the Conference of Librarians which organized the American Library Association in $1876 .^{4}$ I pick an older statement of the problem, first, to help avoid any hysterical wringing of hands. A crisis is something to be met, not something to excite hysteria. I pick it also to emphasize the fact that this crisis is new in certain particulars only. To be sure, it is serious, but it has been serious at other times, too, notably in the fifteenth and the nineteenth centuries. I have no doubt that twentieth-century man will meet the situation as resolutely as his predecessors did.

In meeting what you are to allow me to call, for short, the research library crisis, we can move in one of three directions. First, we can depend on going straight ahead. We can stick to a tradition which has come down from much simpler times, let each library go its own sweet way, collect exactly as its budget and local needs prescribe

4 Library Journal, r:92, Nov. 30, 1876. 
and disregard any regional or national problems not met adequately by the unsupplemented efforts of individual research libraries acting each without reference to the others. Second, we can depend on reorganization. We can let the individual library continue to use its budget to meet local needs, as it sees them, but isolate those functions or activities which lend themselves to being institutionalized and which can be done more efficiently or more economically if thus centralized. We can then create a central agency-a regional library of a new type - to support these special functions and use voluntary cooperation to get the regional library going and get it independently financed. Third, we can depend solely on what we can do through voluntary cooperation, paying no thought to questions of reorganization otherwise. That is, we can call on each library not merely to serve the clientage it is chartered to serve, but to take on a fair share of whatever additional responsibilities are deemed to be in the regional or the national interest and finance the supra- or extra-local responsibility out of savings made through voluntary cooperative agreements on collecting and storing material; and if these savings are not enough, out of funds added to the local library budget to enable it to bear its share of the extra cost.

There may be other alternatives to these, but no others have so far articulated themselves, so we seem justified in confining the present discussion to these three. $U p$ to a point, the second and third courses are not mutually exclusive, but they involve such different methods of attack and will yield such different results in the end that they deserve to be considered separately.

The first alternative need not detain us long. As late as the medieval period, the whole literature available to an age was embodied in no more than a few hundred works. Libraries of record thereafter were able to continue to collect everything of importance for research till around the beginning of the twentieth century. The British Museum, for example, gave up trying to do that in the first quarter of the century and, before or afterward, every research library in existence found it necessary to follow suit. In consequence, we have today no bona fide library of record, and the probability daily becomes more remote that we shall ever have anything of the kind again. In consequence, only a stray professor and no librarian I know believes any longer that our libraries can each go it alone and get us far enough. Even if each research library could single-handedly serve its own clientage well enough, the sum of these single-handed efforts would not add up to a sound research library program for the total society of which the library is a part.

This brings us to the second alternative, reorganization. The goal immediately ahead would be a regional library which would stand on its own feet financially and have its own work to do for the region and the nation. Its relation to existing libraries would be that of an ally or auxiliary, not that of a competitor. It would not be a "super-library" in aspiring to outdo existing libraries and secure for itself a copy of every publication required for research in the region. Its aspirations would be different and less local, less self-centered. It would be charged with helping organize regional coverage of the kind just suggested, would in fact assume heavy responsibility to make such coverage a reality, but would leave as much to other libraries as the latter can dependably handle on their own. In thus rounding out and "sparking" a regional program, this library would be a new organ distinctive enough, important enough and alive enough to encourage a network of re- 
gional activities to grow up around it. It would seek to institutionalize the handling of activities necessary to create the interdependence of a regional system where no system now exists. It would promote such interdependence better than voluntary commitments will do because it would have back of the commitments it made in the public interest enough public support to inspire confidence on the part of other institutions in its capacity to make good on those commitments.

One can already find in the South, in New England and the Midwest centers which could possibly be developed into regional libraries with the kind of program and the independent support just described. The name of the Midwest Inter-Library Center certainly suggests a search for a program broader than interlibrary dependence on warehouse space for sloughed-off books; whereas the Joint University Libraries is, I suppose, as good an example as we could find of an existing local library which could adopt the nonstorage conception outlined in the preceding paragraph and take on larger regional responsibilities, provided it had at its disposal special funds supplied for the purpose of keeping these regional responsibilities from losing out to local needs in the competition for the funds now at its disposal. But if such possibilities reside in existing centers, others are better equipped than I to speak of the fact, so I shall have recourse to ideas and language current in the Northeast where plans are maturing which, if perfected and given the necessary public support, promise to meet successfully the research library crisis as it affects that region. Certain directors of libraries lying mainly along the Atlantic seaboard are working together on this plan, but I shall need for present purposes to refer only to the work of an overlapping group, a New York City steering committee on library cooperation which in the last two years has worn out more chair cushions in discussing this highly complex problem than the most industrious patrons of the New York Public Library in the same building where our meetings have been held.

Most of our time in $1950-51$ was devoted to the kind of acquisitions program a northeastern regional library should have, and the results are embodied in a statement prepared by Jerome K. Wilcox entitled "The Acquisition Program of the Regional Auxiliary Library." Here are some of the highlights of that document. The regional library would take as much responsibility for foreign material now coming to the region as it is asked to do. It would accept from other libraries material which they no longer wish to keep but which should be preserved in the region. It would not collect incunabula, Americana or other rarities. It would be prepared to assume heavy responsibility for rounding out regional acquisition of current publications in the following categories: official publications of the U.S. government (federal, state, municipal, county), of foreign governments, international organizations; periodicals and other serial publications which are out of the way but significantly document contemporary life (publications of bar associations, of law societies; administrative publications of institutions of higher learning; publications of state and local historical societies; proceedings, reports, journals and other publications of learned, scientific and technical societies, U.S. and foreign; publications, reports, journals and other publications of trade unions, commercial organizations, religious bodies, national patriotic societies and veterans organizations, etc.); and finally, certain miscellaneous publications such as foreign dissertations and trade catalogs. Current material in these various categories would be systematically collected 
by the regional library, but it would not expect to get back files of such limitedaudience publications except by taking over back files already in the region. Files of material intended for larger audiences and still actively used by many readers would be left to other libraries to build up.

The Wilcox statement is part of an interim report for 1950-5I prepared by the committee covering such additional points about a northeastern regional library as location, control, method of financing and services. It would take us too far afield to consider such matters here. The narrower object at the moment is to suggest a turn which it is possible for the development of research library service to take as a means of coping with a crisis in which an adequate acquisitions program is crucial. Perhaps, therefore, enough has been said to indicate that one way out is reorganization of the pattern of research library service whereby greater interdependence and greater total strength will be fostered among the various libraries of a region by inserting a new mechanism in the total set-up; or, to borrow a figure from biology to express the same idea, by inserting a new organ the function of which will be to give the region better health and strength bibliographically by developing new tissues of interdependence where genuine interdependence can now hardly be said to exist.

It can be urged against this course that it is too bold, too much of a break with the past and ahead of our times. If these prove too much for us we can still depend on voluntary cooperation to take us as far as it can, and that is the third alternative.

The audience knows well how fruitful voluntary cooperation has been in research library development. What would be more natural or more proper than to fall back on it once more when, somewhere between the depression and the present, we saw the re- search library heading into this midcentury crisis? First came the New England Deposit Library. It was a pioneer development in cooperative storage, perhaps best described as an off-the-premises warehouse or annex designed to serve not one library but all libraries in a region which chose at the outset, or which choose later, to come into the cooperative arrangement. Its main purpose was to provide cheap storage. It was located far enough away from any of the libraries, from coffee shops and hotel facilities to underline the idea of pooling warehouse facilities, but it was at the same time a way of reaching out to find something more than storage, which was correctly seen to be only a piece of a solution to the threatening crisis. It was hoped that "eqoperation between the libraries connected with the new institution will (I) do away with a good deal of unnecessary duplication that has already taken place, (2) prevent additional unnecessary duplication in the future, (3) provide for the advantageous disposal of the unnecessary duplicates, (4) help to bring about a suitable division of fields between the cooperating libraries as far as research material is concerned, and (5) make readily available to all the libraries the little-used books of any one of them."

Then came the Farmington Plan which is as close to a national program as research libraries have thus far devised. Worked out a few years after the first cooperative storage library was created, the Farmington Plan made specific provision for division of fields and for the fixing of responsibility for developing them. The plan calls on each cooperating library for four things: (I) To continue the support of its local program of instruction and research; (2) To accept in addition primary responsibility for developing certain fields; (3) To unite with other

${ }^{5}$ Library Quarterly, 12:628, July 1942. 
libraries in this and other ways to insure serious readers throughout the nation access to at least one copy of each foreign work deemed important for research; and (4) To join in determining whether enough savings cannot be effected through such efforts to hold library costs to approximately their present level. The storage-Farmington formula, if this short-cut expression is acceptable, thus yields when considered as a unit a coherent program for meeting the research library crisis. It draws a bead on two targets in plain sight-the costs of space and material. It is the essence of simplicity, involves a minimum adjustment of our habits, a minimum new money and essentially no channels of action not provided automatically by volunteer institutions.

Here, then, are three courses open to us as we head into the second half of the twentieth century. Which one are we going to take? As indicated, the choice is mainly between the second and the third. Since research libraries have already committed themselves experimentally to the third, is it any good to discuss the other?

I believe so, and suggest five reasons why.

First, the advantage of continual appraisal of what we are doing. We shall wish to support the Farmington Plan until some improvement is worked out, but it is up to us to find out where improvement is possible. A reasonable attitude to take toward our commitments as members and friends of the Association of Research Libraries might be borrowed from an eminent American who in another connection wrapped up the spirit of loyalty and the spirit of sympathetic criticism in one package by saying, "I am for my country right or wrong; if right to keep it right ; if wrong, to set it right."

Second, the lack of dependability in present volunteer commitments. When a university library volunteers cooperation in helping round out the research facilities of the region or nation, it does so with the implied understanding that if the going gets rough financially and supporting the supraor extra-university program conflicts with supporting the university program itself, the conflict will be resolved in favor of the university program. The spirit of the volunteer is willing enough but his flesh is too weak to give trustees of other universities assurance that if they modify their own collecting policies and depend on the volunteers, they will be on safe ground.

Third, the hoped-for savings from participating in the Farmington Plan have not yet materialized. It is too early to tell whether greater savings will not come in due course, particularly if supplemented by cheap storage. Will they be great enough, even so, to freeze budgets where they are, as hoped at the outset? Possibly, but for the library system which was already buying selectively when it entered the present cooperative arrangements, the signs are not very encouraging. They point rather to the likelihood that the public will be called on to pay a larger bill for research library service or accept a lower standard of service which will cost heavily in other ways. If increased costs cannot be skirted by savings through cooperative arrangements, it will pay us to give more thought than we have given since inaugurating the Farmington Plan to developing new support. A regional library of the kind here envisaged would tap new support and at the same time keep the total bill for research library costs below the costs required to maintain the same standards of service without a central agency of this kind.

Fourth, the need of bolder measures for the long pull. We are now fighting what amounts to a rear-guard action. This is good enough as a rescue measure, but not 
good enough to cope with a crisis that requires us, as this one does, to do something besides waiting on what happens next.

Fifth, the practical limits of volunteer action in a situation of this kind. In the Dunkerque rescue of 1940 , the British threw in every seaworthy vessel in reachtugboats, yachts, fishing boats, everything. His Majesty's Navy rose to exceptional heights by calling on civilian facilities and personnel to do double duty. More recently, we saw in the army of the Dalai Lama, the god-king of Tibet, an instance where double-duty measures were applied more consistently as a matter of public policy. In organizing resistance to the advancing Communists, the nation leaned heavily on young nobles who, like their counterparts in the West in feudal times, marshalled each his own retinue of servants and went out to help fight the common enemy.

The thing that strikes us as unusual in the Dunkerque "navy" and the Tibet army is not the evident civilian willingness to cooperate to the point of doing double duty but the use of volunteered support as a method-a method of getting action when, where and in the amount needed. Mobilization for total warfare nowadays depends no less on a willingness to cooperate, but it uses a very different method of organizing the joint undertaking in order to get action when, where and in the amount needed. To seek to achieve the smooth fighting effectiveness of a modern nation through the feudal methods of the Dunkerque navy or the Tibet army would be to strain, to overextend the practical limits of voluntary cooperation.

This paper will have served its purpose if it shows that the university library-more broadly, the research library-is striking pressures in our time which will force a turn in its course, and if it promotes fruitful discussion of alternatives. Some libraries will undoubtedly seek to forge a course straight ahead and may succeed in doing so to their own satisfaction; but the burden of the argument here is that an adequate national research policy-an adequate program for the institution, the research library-cannot be worked out along this line. If we are to maintain the standards of library service which America's research interests have come to rely upon, it seems necessary to institute reorganization proceedings of some kind or turn to a circle of hard-pressed institutions to volunteer to carry an ever-larger share of mounting supra- or extra-local responsibilities. Both courses make use of joint effort, but in different ways and on a different scale. The central problem is how society can, through its representatives, find the best way to enlist cooperation on the scale necessary to meet the crisis. The most fruitful course seems to call for a new division of labor which will transfer to a regional library created for the purpose extra-local responsibilities which local research libraries more and more now find themselves bearing. This course would not only keep the contributions of the present hard-pressed institutions within practical limits they can stand, but would at the same time open the way for individual citizens, private organizations and public bodies, having a stake in the outcome but no direct interest in the institutions now shouldering the load, to join in the cooperative effort. 